\title{
Active Alumni in Electrical Engineering Extracurricular Activities: Innovation and Social Responsibility
}

André Bezerra de Freitas Diniz, Bruna Luisa Martins Barbosa, Dênnyson Eliseu Araújo Santos, Max Rodrigues Marques and Victor Matheus de Câmara Silva

Department of Electrical Engineering, UFRN, Natal, Brazil

\begin{abstract}
The project analyzes the student's participation in complementary activities such as Education Tutorial Program, Junior Company and Academic Center. These organizations have the goal to improve, expand and connect knowledge learned during classes with several practical activities. They can provide a huge integration between the students and the professors in order to achieve better results in the pedagogical, structural and organizational parts of an engineering major degree. Therefore, the project goes through the impact of each entity in the student's life and the advantages to professional future, focusing the presence of these organizations in the Electrical Engineering Course of Federal University of Rio Grande do Norte.
\end{abstract}

Key words: Complementary activities, education tutorial program, junior course, academic center, electrical engineering.

\section{Introduction}

The Electrical Engineering course in UFRN is the second oldest in the state, created in the first semester of 1969 and went through a structural reorganization in 1996, as a result of several evaluations and discussions in the past years, both in local and national aspects, around the teaching of engineering. The last reform happened in 2016, and, as outcome, a modern and flexible curriculum, according to the demands of the contemporary market. The objective is to form electrical engineers who are capable of working in the following areas: Control and Automation Systems, Electronics, Power Systems and Telecommunications. Today, UFRN provides 90 vacancies for prospective students every year, with entry in the first and the second semester.

In 2007, the Tutorial Education Program (Programa de Educação Tutorial) was created for the course,

Corresponding author: André Bezerra de Freitas Diniz, undergraduate, research fields: power systems and embedded systems. Bruna Luisa Martins Barbosa, undergraduate, research field: control systems. Dênnyson Eliseu Araújo Santos, undergraduate, research field: communication systems. Max Rodrigues Marques, undergraduate, research field: power systems. Victor Matheus de Câmara Silva, undergraduate, research field: power systems.
PET-EE, which is a program held by the federal government of Brazil, in order to inspire research, teaching and extension activities in the university and also outside of it. In UFRN the program is composed by 15 undergraduation students and 1 teacher as a tutor, working alongside to provide mini-courses, scientific and technical events, new trends in technology for research and help with the course subjects to other students. Furthermore, in 2014 the CA-EE (Academic Center of Electrical Engineering) was created, which has represented the students' opinions alongside the decisions made by the course's department. More recently, during July 2015, LUMUS, the first Junior Company of the course was founded, aiming the preparation of the students to the job market, as well as an environment to develop future entrepreneurs and leaders with social responsibility and acting with principles such as ethics, proactivity, group work, innovation and professionalism.

The main article objectifies to value the significance that the complementary activities bring to the academic life of many other students, analyzing the impact that these 3 entities have on an academic 
and professional formation. This paper has been written by students of PET-EE, CA-EE and LUMUS, in order to scrutiny the obtained results.

\section{Student Organs}

Below are described the main activities of each entity mentioned, how they began, obtained results and why they exist.

\subsection{CAEE, Academic Center of Electrical Engineering}

Aiming to have student representation in academic, political and social character, the CAEE was created as the highest entity for this purpose in the Electrical Engineering Course in UFRN. Composed by a group divided through smaller departments, it is elected democratically every year, with previously inscribed plates formed by regularly students enrolled in the course.

The struggle for representation has not always been present in the course: only on 11 November, 2014, the statute for the creation CAEE was built. It is firmly related to students who felt the need to give opportunity to UFRN's alumni opinions, spreading this idea via SIGAA, the university's online platform of communication. In this way, they held the support from many teachers who felt the same.

Since then, CAEE has gone through 3 elections, and the current administration is divided into 6 co-ordinations: General, Administrative and Financial, Social, Communication, Academic and Sports and Culture. Nowadays, they are occupied by 13 effective members with other 14 adjunct collaborators.

Its action on the academic scope covers the responsibility of promoting the union of the teachers' group, as well as integrating it to alumni and administrative technicians inside the institution, mainly in the DEE (Electrical Engineering Department), always preserving its autonomy and hierarchical position. For example, there was considerable participation from CAEE during the discussion for a new curricular project to be implemented in 2017, with continuous search for students' opinions and bringing them to meetings alongside DEE. Other acts include struggling for the implementation of policies that facilitate the permanence of students in the institution, better labs, more books available in the library, bigger requirement during classes and reporting to the department eventual actions held by teachers that collide with principles of ethics and respect.

In the social field, CAEE aims to apply interventions that are able to promote everyone's inclusion in academic, political and social environments. As an example, the "godfather" activity: the newest students are helped by designated veterans in the course, so that they can help the recently arrived ones with topics such as how to organize studies, how to use UFRN's library and so on. There are other activities regarding debates on many topics regarding current events in Brazil, always respecting each other's differences, providing discussions that help the exercise to respect one another and contributing to social progress.

In July, 2016, CAEE contributed to organizing XI ENEEEL (11th National Meeting of Electrical Engineering Students), which happened in Natal-RN, when a higher visibility was given to UFRN in national scope, also providing new partnerships and ideas that can make a difference in the job market in the future.

\subsection{LUMUS, Electrical Engineering Junior Company}

LUMUS Engineering is an initiative of junior companies in the Electrical Engineering course, founded on July 15, 2015. Its mission is to offer high quality services to its clients and promote a market experience to the academic community, as well as developing an entrepreneurship spirit.

The vision is, in 2017, to be a well structured company, federated to RN Junior (State Junior Companies' Federation), being seen as a better formation opportunity inside the electrical engineering 
academic community and obtaining financial sustainability. Through the main principles of a junior company, LUMUS has 6 important values: pride, proactivity, entrepreneurship, safety, client satisfaction and socio-environmental responsibility. All these topics were chosen so its participants always search for doing beyond the necessary, finding innovative solutions and the best solutions.

During each semester, the company tries to engage into selection process, aiming to reach as most electrical engineering students as possible, in such a way that there is constant renovation between the integrants. After the selection and the effective entry of the members, LUMUS promotes capacitation courses on areas such as electrical installations.

Today, the company acts in a ramified shape, according to its directories, each of them having its own missions that, together, seek the progress. The presidency is currently studying the possibility of partnerships and also being responsible for representation in face to Movimento Empresa Junior Potiguar (Rio Grande do Norte's Junior Company Movement). Alongside, the vice-presidency, which seeks better forms of performance and internal

\section{ORGANOGRAMA}

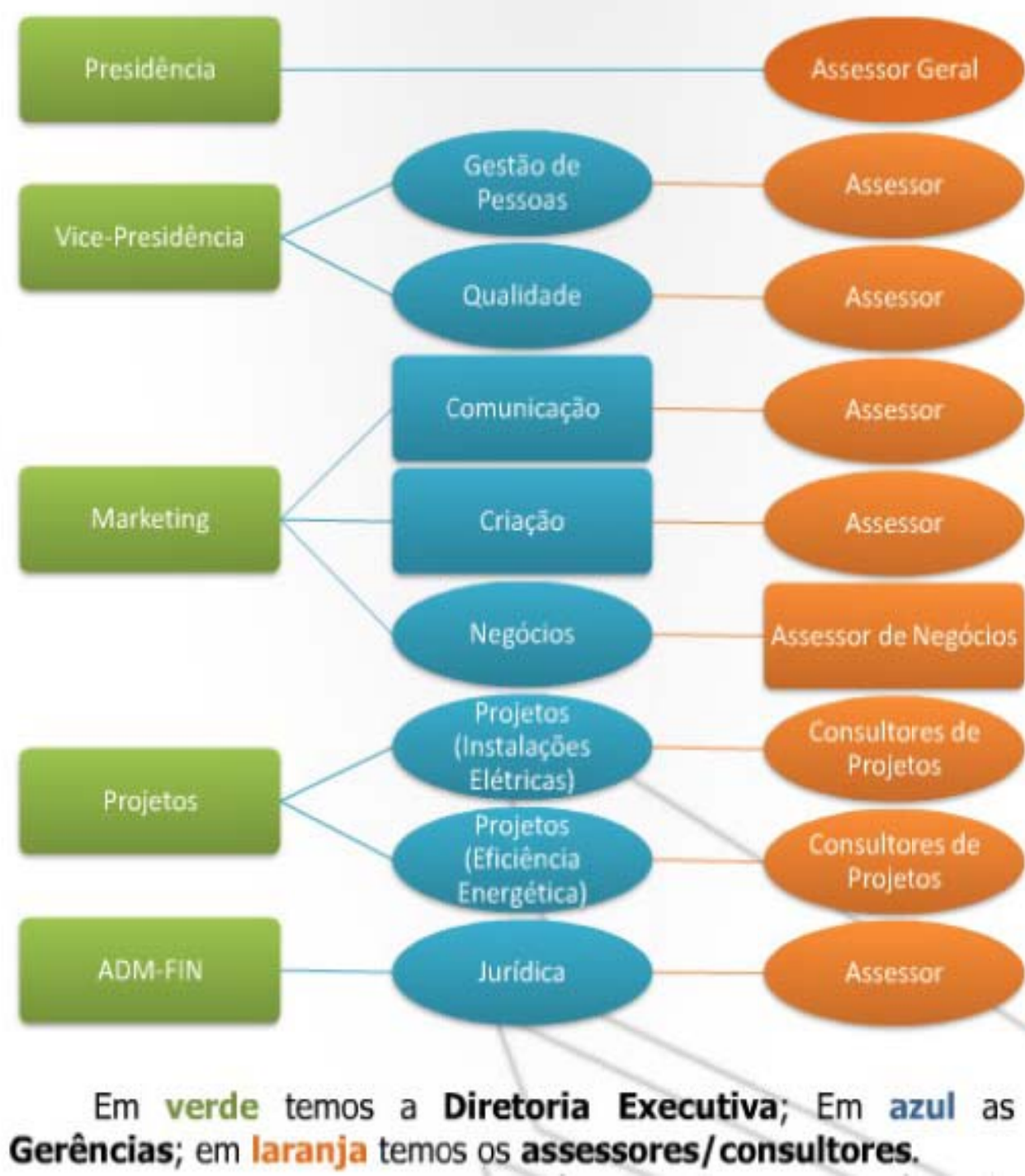

Fig. 1 Segmentation of the company. 
communication evaluation, as well as management system capable of organizing LUMUS' goals, building the activities for the team integration. The marketing directory is designing a web page and the best way to reach the public via social media. The project branch is working on a consulting project for CCHLA, one of UFRN's departments and has done a trainee program during the second semester of 2016 to its newcomers. Meanwhile, the administrative directory is elaborating the necessary documents for recognition alongside federal entities of Brazil.

The offered services include energetic efficiency consulting, power factor correction, lighting techniques and electrical installations. These activities reduce the value of the energy bill for consumers, also making equipments last longer and a better use of natural light.

With this in mind, LUMUS has, each day, turned into an interesting opportunity to many students who want a professional experience before finishing the course, with an entrepreneurship characters. Participating in a junior company, it is possible to understand the operation of an enterprise and how it works; to assume administrative roles with visions and responsibilities for leadership; to make contact with micro and small businessmen; to apply knowledge taught during classes; to develop networks and relationships with all involved with junior companies, as well as business plans and sectoral analysis, learning how to behave while in a company.

\subsection{PET-EE, Electrical Engineering Tutorial Education Program}

As described in MOB (Basic Orientations Manual), the PET program is made by other tutorial groups across Brazil and seeks to provide its integrants, under the orientation of a professor, conditions to realize extracurricular activities which might complement their academic formation, attending the course's own necessities, maximizing and deepening its objectives and the curricular subjects. Founded in September
2007, PET-EE was initially composed by 6 students and a tutor professor and today it counts with 15 participants and 1 teacher. In this way, the group acts in 3 main terms: research, teaching and extension.

In the research field, the "petians" produce scientific material through many bases in UFRN, oriented by teachers across it. Today, members act in various topics, such as robotic football, electromagnetic frequency regulators, image processing and RFID. Also, their results are exposed in scientific fairs (CIENTEC, CIC, National Congress for Teaching in Engineering), showing applications developed by them, which include: a controlled system for the entrance of cars using RFID, home illumination with an Android app and a light-seeker mini-car with Arduino.

Extension activities develop actions not only for students outside the university, but also for many inside of it. It is possible to exemplify these attitudes with the "Engineering at School” program, where they look to attract students of public and private schools to electrical engineering, via the exposition of the areas of performance and its applications, as well as themes involving entrepreneurship in engineering and job market. To the undergraduation students, PET-EE organizes every semester technical visits to sites where electrical engineers act, including power stations, CLBI, CTGAS-ER and many others. Another situation is the organization of events that involve many students from UFRN and other universities, as can be mentioned: the Electrical Engineering Workshop (which will reach its 7th edition) and Electrical Engineering Challenges (giving prizes to groups that solve a broad problem with tools taught during classes).

Teaching is also a large branch of PET-EE, where mini-courses are one of the main activities. During their realization, "petians" teach the use of tools (MATLAB, Arduino, LaTeX and others) for students enrolled in many other courses inside UFRN. Peer tutoring is made too, aiming alumni from all levels in 
the course as well as for CIT (Introduction to Technological Areas Course), offering support for recently arrived students, teaching them subjects that are not studied during the final years of school and are basic for an engineering course.

One of PET-EE's goals is to make graduation not only an academic achievement, but to develop important skills to an engineer formation too, so that their activities reflect on the others around the group.

\section{Future Actions}

It is expected, in a not very long future, to obtain higher participation from the alumni in extracurricular activities with the establishment of an IEEE Student Branch, collaborating with its global increasing and promoting knowledge for creation, development, integration and other values so the profession of Electrical Engineer and humanity itself can benefit from these actions. In that way, UFRN students can have a bigger visibility.

Another topic is reducing scholar evasion, which today is a major issue: only $45 \%$ of those who enter the course actually get to finish it. The goal is to start reducing this number to $40 \%$ at first, through the activities from CAEE, PET-EE and LUMUS.

\section{Conclusions}

The three mentioned entities have been demonstrating expressive results in such a relative small time of existence. As for 2017, more than 80 students have gone through PET-EE, 21 through LUMUS and 45 through CAEE. All of them have, undoubtedly a singular formation, with leadership practice, team work, pro-activity and incentive, speaking to a public and making connections stronger.

PET-EE has reached a number of 10 annual mini-courses, which include MATLAB, GNU Radio, Excel/VBA, Arduino and others. Also, it is working on the 7th edition of UFRN Electrical Engineering Workshop, bringing mini-courses and speeches about varied subjects to more than 108 students, with direct interaction between companies and them. It should be not forgotten that many "petians" work have been recognized with participations such as a 5th place on the National Robot Soccer Cup, invitation to international congresses and to ministration of mini-courses in Macaé-RJ. Another topic is the number of technical visits provided: 2 have already been realized in the first semester of 2017.

In 2015, CAEE was able to transport 28 students to Paulo Afonso-BA, where the 10th edition of the National Electrical Engineering Students' Meeting happened, as well as a technical visit to Paulo Afonso IV power plant. This was only achieved after a long struggle with the course's department and coordination and also the university's rectory to allocate a bus for transportation and other resources. The representativity was so well done that Natal was chosen to receive the 11th edition of the event. Also, a major achievement happened in 2014: after prejudicial misconducts from a professor, he was turned away, making him forbidden to lecture mandatory subjects.

LUMUS, which started with 8 members, as the first electrical engineering junior company in the state, has grown the number of components to 21 in less than a year, bringing them knowledge through professional courses and experience to the job market with participation in expressive congresses on junior companies, as an option to the ones who want to live the entrepreneurship life. Also, it has been accepted to RN Júnior, Rio Grande do Norte’s Junior Company federation, as well as bringing services to leading establishments in Natal, such as Dental Médica and Nutre.

\section{References}

[1] Department of Electrical Engineering, UFRN. 2006. "Projeto Político Pedagógico do curso de graduação em Engenharia Elétrica da UFRN.”

[2] Brazil's Ministry of Education, 2006. "Programa de Educação Tutorial-Manual de Orientações Básicas.” 
112 Active Alumni in Electrical Engineering Extracurricular Activities: Innovation and Social Responsibility

[3] Programa de Educação Tutorial-Engenharia Elétrica (UFRN), 2016. "Regimento Interno."

[4] “Empresas Juniores.” 2017. Retrieved from http://www.nit.ufrn.br/paginas/empresas_juniores.

[5] LUMUS Engenharia, 2015. "Estatuto Social.”

[6] Centro Acadêmico de Engenharia Elétrica (UFRN), 2014.
"Estatuto Social."

[7] Law no. 13.267, 2017. Retrieved from https://www.planalto.gov.br/ccivil_03/_ato2015-2018/20 16/lei/113267.htm.

“Torne-se um Empresário Júnior.” 2017. Retrieved from http://www.cemj.propesq.ufrn.br/pagina.php?a=empresario. 